\title{
The secularisation of St Francis of Assisi
}

\author{
Mary Heimann \\ Professor of Modern History, School of History, Archaeology and Religion, \\ Cardiff University, Cardiff CF10 3EU. Email: Heimannm@cardiff.ac.uk
}

\begin{abstract}
St Francis of Assisi, mystic, stigmatic and founder of the Franciscans, has come to seem uncontroversial, a saint for ecologists, socialists and animal lovers as well as Christians of all denominations. Until his rediscovery by the Victorians, Francis was firmly associated with Roman Catholic doctrine, obedience to the papacy, participation in crusades and distinctively Catholic mystical phenomena. This article argues that Faber's, Oliphant's and Sabatier's nineteenth-century Lives of St Francis opened the way for his appropriation by the general British public. The resulting denominational competition over the saint stimulated a boom in St Francis' popularity but also led to his piecemeal secularisation.
\end{abstract}

Keywords: Saint, Francis, Assisi, Victorian, English Catholic, Lives of Saints, Popes, Secularisation

In March 2013, immediately after his election as pope, Jorge Mario Bergoglio held a press conference at the Vatican during which he explained his reasons for choosing the papal name Francis. 'During the election,' he explained, 'right away, thinking of the poor, I thought of St Francis of Assisi' and then 'of all the wars'. 'Francis,' he reflected:

is also the man of peace. That is how the name came into my heart: Francis of Assisi. For me, he is the man of poverty, the man of peace, the man who loves and protects creation; these days we do not have a very good relationship with creation, do we? He is the man who gives us this spirit of peace, the poor $\operatorname{man} . .1$

In his quick characterisation of St Francis of Assisi as 'the poor man', 'the man of peace' and 'the man who loves and protects creation', Pope Francis I was drawing upon thoroughly modern understandings of the thirteenth-century saint who took literally the gospel injunction to 'sell all you have and give it to the poor' and was so in tune with

Versions of this article were read at the Royal Historical Society conference on Modern Religious History (University of Stirling, 2016) and the Catholic Record Society conference (University of Cambridge, 2016). My grateful thanks to the organisers and participants of both conferences - especially David Bebbington, Clyde Binfield, Susan O'Brien, Carmen Mangion and Liesbeth Corens - for their inspiring work and thoughtful suggestions.

1 Anon, 'Pope Francis reveals why he chose his name', The Catholic Herald (16 March 2013). 
nature that he sang in praise of Brother Sun and Sister Moon and preached the word of God even to the birds. ${ }^{2}$

The poor man of Assisi has come to seem universal: a saint for all times and places. Remembered selectively, and sentimentally, as a wandering holy man imbued with compassion for all living things, St Francis of Assisi is attractively accessible, as easily approached by a Buddhist as a Christian, an ecologist as a Hindu. But although St Francis of Assisi has come to seem uncontroversial, as open to Protestants as Catholics and to non-Christians as Christians, historically speaking this is a very recent development.

For a good five hundred years, Francis of Assisi was understood to be quintessentially and exclusively Roman Catholic, an obedient son of the Church of Rome whose simplicity of faith and obedience to his ecclesiastical superiors was held up as a model for other Catholics to follow. ${ }^{3}$ Although claimed, long after the Reformation, as a religious reformer who spoke truth to power, a sort of proto-Protestant or proto-socialist rebel, Francis appears in fact to have stayed close to the Catholic Church throughout his life and to have avoided any taint of heresy or disobedience.

Francis was, of course, the founder of two important Catholic organisations still in existence: the friars minor or Franciscans; and the lay society known as the tertiaries or Third Order of St Francis. He was also the inspiration for a third: the Franciscans' sister congregation of the Poor Clares. This took organisation and planning. Francis was no wandering mystic. It was not from a voice in the wilderness, or even from a burning bush, but rather from a crucifix at San Damiano's church near Assisi, that he first heard a voice instructing him to 'go and repair my house, which you see is falling down', ${ }^{4}$ which Francis initially understood literally as a divine command to go and restore derelict churches in the vicinity of Assisi. It was again in church, while hearing mass at the chapel of Our Lady of the Angels (better known as the Portiuncula), in the plain below Assisi, that Francis, in response to hearing the biblical text 'do not possess gold... nor two coats nor shoes nor a staff, ${ }^{5}$ was moved spontaneously to give away his clothes and put on the simple tunic, belted with a length of rope, that was to become the Franciscan

${ }^{2}$ For a quick summary of Francis' life, see for example 'St Francis of Assisi' in F. L. Cross and E. A. Livingstone, eds. The Oxford Dictionary of the Christian Church, $3^{\text {rd }}$ edn. (Oxford: Oxford University Press, 1997), 632-3.

3 The extent to which Francis's immediate contemporaries shaped his life to correspond to their own expectations of sanctity lies beyond the scope of this article, but see especially Eamon Duffy, 'Finding St Francis: Early Images, Early Lives', in Peter Biller and A. J. Minnis, eds. Medieval Theology and the Natural Body (York: York Medieval Press, 1997), 193-236.

4 [Alban Butler], Butler's Lives of the Saints, eds. Herbert Thurston and Donald Attwater, 4 vols (London: Burns Oates, 1981 [1956]) (Hereinafter cited as Butler's Lives of the Saints), 4: 23 .

${ }_{5}$ Luke 9:3. 
religious habit. Even his famous withdrawal to La Verna in the Apennines, where he experienced visions and, on Holy Cross day 1224, mysteriously received the stigmata (marks of Christ's wounds) on his body, did not take place in a prophet's wilderness but at a wellestablished place for spiritual retreats put at his disposal by the lord of Chiusi and owned by local Benedictines. ${ }^{6}$

Francis evidently saw no contradiction in simultaneously following gospel counsels of perfection, seeking the approval of his ecclesiastical superiors and obeying Church instructions. He insisted that his followers should respect the wishes of parish priests and local bishops and stated explicitly that any member of his community who 'stray[ed] from the Catholic faith or life in word or in deed' should immediately be expelled from the brotherhood. ${ }^{7}$ The laws that Francis drew up to regulate the communal life of his followers were taken directly to the highest ecclesiastical authority, the pope, for approval: Francis took care to show the first sketch of the community that was to become the Franciscans to Innocent III in person. He also saw to it that the final rule governing the friars minor was issued, in a papal bull of 1223 , by Honorius III. Even when he was dying, Francis is recorded as having made a point of commanding his brethren always to remember to 'love and honour the clergy of the Church'.

Obedient to mysterious voices from the high altar, Francis was equally eager to respond to papal directives. It was in response to Innocent III's appeal at the Lateran Council in 1215 for a new crusade to reclaim the Islamic world for Christendom that Francis determined to help convert the Muslim 'infidel'. In 1219 Francis, together with twelve friars, set off from Ancona for the Holy Land. Although they were forced to turn back in 1212 because of bad sailing conditions in the Adriatic and again in 1213 because Francis fell ill in Spain, in 1219, in the company of Gautier de Brienne's crusaders, Francis finally succeeded in crossing to the Muslim side near Damietta in Egypt. It was here that Francis attempted to persuade Sultan-alMalik-al-Kâmil to become a Catholic. 'If you and your people will accept the word of God,' he is reported to have told the sultan, 'I will with joy stay with you. If you yet waver between Christ and Mohammed, cause a fire to be kindled, and I will go into [it] with your priests that you may see which is the true faith'. ${ }^{9}$ After the sultan and his imams refused to accept the challenge, Francis returned to Italy via Palestine, where he made his pilgrimage to the Holy Land. According to later accounts attributed to St Bonaventure, the sultan later

6 For all these elements see, for example, 'Francis of Assisi' The Oxford Dictionary of the Christian Church, 632-3.

7 As cited in Butler's Lives of the Saints, 26.

8 Ibid., 30 .

9 Butler's Lives of the Saints, 28. 
converted in secret, or accepted a deathbed baptism, as a long-term consequence of this brief, but impressive, encounter with Francis. ${ }^{10}$

The pattern of obedience to Catholic teaching and Church authority that can be seen in Francis's life and the rule he established for his followers was further underlined in his own, doctrinally impeccable, spirituality and that which was promoted by the religious foundations he created. Although Francis's enthusiastic literalism in accepting the gospel command to 'sell all you have and give it to the poor' was shared by the Waldensians, Francis refrained from following them in preaching without formal permission or in criticising the Church for worldliness. He was similarly careful to avoid the heretical ideas of the Albigensians, making explicit that equal stress should be given to the humanity and to the divinity of Christ. Nor was there any Wycliffite, Hussite or proto-Protestant minimalism about the Franciscan approach to the saints. It was in order to express devotion to the Blessed Virgin Mary that each of the orders that Francis founded insisted on the observation of the thrice-daily Angelus, with its repetition of the 'Hail Mary'. Devotion to Mary led Franciscans of all kinds to be associated with the ardent defence of the doctrine of the Immaculate Conception as early as the fourteenth century, a good six centuries before its dogmatic approval in $1854 .{ }^{11}$ Approved Catholic doctrine was further spread through Francis's promotion of Christmas cribs as a means of contemplating the central mystery of the incarnation through close attention to the infant Jesus and the holy family. Orthodox doctrine was also taught through the Franciscans' early concentration on Christ's passion in the ritualised devotion known as the 'stations' or 'way' of the cross. This devotional practice, which offered a substitute pilgrimage to the Holy Land while at the same time stressing the central importance of penance, spread from Franciscan communities to all corners of the Catholic Church over the course of the nineteenth century and became a standard feature in Catholic churches worldwide.

Francis and his followers were rewarded for their loyalty to the holy see by being granted official sanctions of approval by a series of popes. It was only a year after Francis's revelation at the Portiuncula and, according to legend, because of a dream in which Innocent III saw the barefoot friar saving the basilica of St John Lateran from collapse, that Francis's first rule for the common life of his disciples was approved in a private interview with the pope of 1209 or 1210. In 1216 , Honorius III was similarly quick to grant the rare privilege of a plenary indulgence to be attached to the Portiuncula, which allowed

10 John Tolan, St Francis and the Sultan (Oxford: Oxford University Press, 2009), 168.

11 'The Immaculate Conception of the Blessed Virgin' in A Catholic Dictionary: Containing Some Account of the Doctrine, Discipline, Rites, Ceremonies, Councils, and Religious Orders of the Catholic Church, ed. William Addis and Thomas Arnold, $9^{\text {th }}$ edn (London, 1917), 440-3. 
pilgrims to the chapel to be rewarded with the removal of the temporal punishment due to their sins.

Francis, having been helped at every stage of his mission by the approbation of the Church, was canonised with remarkable speed. In July 1228 , less than two years after his death in October 1226, Gregory IX officially declared Francis to be a saint. He had, as the English Catholic hagiographer Alban Butler put it, already 'entered into glory in his lifetime'. ${ }^{12}$ St Francis's popular appeal was further enhanced, after his death, by the publication of three especially influential pious biographies: those attributed to St Bonaventure, Thomas of Celano and the Tres Socii or Three Companions. All three of these early hagiographies stressed Francis's conformity to the perfect Christian model and recorded signs and wonders as additional evidence of his particular favour with God. In addition to being associated with other miracles, Francis was claimed as the first stigmatic, being reported by all three sources to have received the impression of Christ's wounds during a vision in which he saw a six-winged seraph enclosing the crucified Lord. He was further said by St Bonaventure to have possessed divine foresight and to have received miraculous communions. The less formalised collection of popular medieval legends about St Francis known as the Fioretti or 'little flowers' of St Francis additionally described how he cured a leper, in both body and soul, by the simple act of bathing him; how he sometimes floated above the ground while praying, ${ }^{13}$ and, most famously, how he stopped a wolf from terrorising the villagers of Gubbio by reasoning kindly with it. ${ }^{14}$ Once reassured that it would stop being chased by dogs or men, the beast put its paw into Francis's hand as a token of his promise to leave the villagers in peace. The wolf was afterwards said to have been as meek as a lamb.

As described by his first biographers, and endorsed by a series of popes, St Francis of Assisi had all the qualities to make him into a prime symbol of Roman Catholic orthodoxy. Francis had an impeccable record of ecclesiastical obedience, doctrinal correctness, devotional depth, papal endorsements, a strong popular following and an impressive legacy in the shape of three religious communities. Francis had renounced worldly wealth, preached the gospel, healed the sick, performed miracles and restored peace. His stigmata suggested to contemporaries that, like the crucified Lord he sought so closely to imitate, he deliberately sacrificed himself in order to

12 Butler's Lives of the Saints, 22.

13 The Little Flowers, the Mirror of Perfection and the Life of St Francis, tr. Thomas Okey, ed. Ernest Rhys (London and New York: J. M. Dent, Everyman's Library 585, 1941), 45-6; 29-30; 55.

14 The Little Flowers and The Life of St Francis with The Mirror of Perfection, ed. Thomas Okey (London: J. M. Dent, 1910), 39-40. 
redeem others. Signs and wonders were said to have followed him as they had followed Christ. We might reasonably expect Francis to have been made into an official embodiment of Catholic 'truth' as opposed to doctrinal 'error': not only against the Albigensian and Waldensian heresies of his own day but also, by extension, the later Wycliffite, Hussite, Lutheran, Calvinist and other proto-Protestant or Protestant heresies which were to follow, most notably during the Reformation and Counter-Reformation periods.

St Francis of Assisi's suitability to exemplify points of difference between Catholic and Protestant doctrine were not lost on rival, Protestant polemicists. Works which presented St Francis as the quintessential popish idol, like Bartolomeo Albizzi's The alcaron of the barefote Friars, that is to say, an heape or number of the blasphemous and trifling doctrines of the wounded idole Saint Francis taken out of the boke of his rules, first published in England in 1542 and endorsed with a preface by no less a personage than Martin Luther, remained in print well beyond the high point of Reformation controversy. Albizzi's own work was reissued in (at the very least) eleven separate English editions over the course of the sixteenth and seventeenth centuries. At least one fresh edition was brought out as late as 1845 .

During the Enlightenment, fashionable distaste for medieval miracles and widespread aversion to mendicant and contemplative orders, combined with the low reputation into which Franciscan communities on the European continent had sunk, ensured that Francis of Assisi's reputation also suffered. Even the Bollandists' Acta Sanctorum (1643ff) dismissed most of the pious stories surrounding the saint as mere fables and legends, its Jesuit editor considering it beneath his dignity to read, let alone draw evidence from, the Fioretti. ${ }^{15}$ By the end of the eighteenth century, the Englishman Hallam appears to have been expressing a widely-held opinion when he pronounced Francis to have been 'a harmless enthusiast, pious and sincere, but hardly of sane mind' who was 'much rather accessory to the intellectual than to the moral degradation of mankind. ${ }^{16}$ The unearthing of the saint's body in 1818 aroused little interest outside Italy, and the six-hundredth anniversary of Francis's death in 1826 went unremarked by nonCatholics. 'The whole world outside the Roman Catholic communion', as Walter Seton put it, then 'thought of him, if it thought of him at all' simply 'as a dead Roman Catholic' who was of no relevance to their lives. ${ }^{17}$

\footnotetext{
15 John R. H. Moorman, The Sources for the Life of S. Francis of Assisi (Manchester: Manchester University Press, 1940), 4.

16 Thomas Okey, 'Introduction' to The Little flowers and the Life of St Francis with The Mirror of Perfection, ed. E. Rhys (London: J. M. Dent, 1950 [1910]), xxi.

17 Walter Seton, 'The Rediscovery of St Francis of Assisi' in John R. H. Moorman, ed. St Francis of Assisi: 1226-1926: Essays in Commemoration (London: University of London Press, 1926), 247.
} 
The earliest Victorian to attempt to rehabilitate St Francis and bring him to public attention as a suitable model for admiration and emulation appears to have been by Frederick William Faber, one of the most flamboyant of the Tractarian converts to Catholicism, and a fervent enthusiast for French and Italian Catholic spirituality. In 1847, Faber translated L. F. C. Chalippe's Vie de Saint François d'Assise as part of a new Oratorian series of religious lives that were intended to re-educate native or 'recusant' English Catholics, thought to have been overly influenced by prevailing Protestant attitudes in Britain, in 'genuinely' Catholic sentiments. Henry Edward Manning, who after his conversion to Catholicism rose to become Cardinal Archbishop of Westminster, brought out the first English edition of the formerly despised Little flowers, again for the edification of his fellow English Catholics, in 1864. In 1867, Cardinal Manning followed this with an edition of St Bonaventure's The life of St Francis of Assisi, London 1925 [1867], which he described in the preface as 'the life of a saint written by a saint'. ${ }^{18}$ To these most self-consciously Roman Catholic converts from the Church of England, the life of St Francis was to be prized above all as an example of how strict obedience to the teaching of the Catholic Church could lead ultimately to a mystical union with God. F. W. Faber was at pains to explain in his essay 'On the interest and characteristics of the lives of the saints' of 1853 that the point of reading religious biographies was not to gain psychological and historical insights into a particular saint's mental world. Rather, it was to extrapolate from his or her life a 'sort of summary of spiritual theology' in a form 'much more attractive than the mere rules of a spiritual treatise, and kindling in us all the while a more personal interest in those who have power in heaven as well as a deeper veneration for them, and a more solid devotion to them. ${ }^{19}$ Since the purpose of devotional, unlike secular, reading was to discern eternal religious truths, rather than individual human quirks or underlying historical principles, Faber warned his readers that 'these Lives must be dull to those who read them for any other object than that of uniting themselves more closely to God', whose life the saints by definition imitated 'more or less literally'. ${ }^{20}$

In accordance with strictly doctrinal understandings of the spiritual significance of the saints, nineteenth-century Roman Catholic lives of St Francis, in England as elsewhere, followed the lead given in medieval texts in strongly emphasising Francis's conformity to the life, as well as

18 [Henry Edward] Manning, 'Preface to the First Edition [1867]', The Life of St Francis of Assisi by St Bonaventure, ed. Cardinal [H.E.] Manning, 9th ed (London, 1925), [3].

19 Frederick W. Faber, The Life of S. Francis Assisi, with an Essay on the Interest and Characteristics of the Lives of the Saints (London, 1853), 28. (Hereinafter cited as Faber, Life of S. Francis).

${ }^{20}$ Faber, Life of S. Francis, 67. 
to the teaching, of Jesus. Stressing the literal correspondences between the two lives, Catholic writers tended to repeat from St Bonaventure that Francis had been born in a stable, joined by twelve disciples, lived a life of holy poverty and, above all, been mystically united to Christ through his voluntary acceptance of what was in effect a second crucifixion. $^{21}$ Far from appearing peripheral, the stigmata were understood as completing Francis's similitude to Christ, and focussing attention on right understandings of self-sacrifice and suffering as central to Christian redemption. It is for this reason that Catholic statues and pictures of the saint invariably showed him displaying the five wounds, or else presented him in cruciform shape; while devotional societies named after him laid stress on the stigmata as a timely reminder of the importance to Christians of penitence and the mortification of self. As a prayer recommended for the use of Franciscan tertiaries begged:

O Lord Jesus Christ who, when the world was growing cold, didst renew the sacred marks of Thy Passion in the flesh of the most Blessed Francis in order to inflame our hearts with the fire of Thy love: mercifully grant that, by his merits and prayers, we may always carry the Cross and bring forth fruits worthy of penance. $^{22}$

From about the 1840s, it appears to have been precisely this sort of emphasis on the value and holiness of suffering, and of the universal need for repentance, which could make the deepest appeal to earnest Christians, whether they came from Evangelical, Anglican or Catholic backgrounds. It was in a climate in which revivalist missions of the 1840s - Catholic as well as Protestant — set out to awaken or sharpen a sense of sin among ordinary Victorians, that a number of Anglicans began to look wistfully at those features of a revived and enlarged English Catholic Church which claimed to offer assured access to forgiveness. As W. J. Butler wrote to John Keble in 1845: 'Many of... my own personal friends, are now repenting bitterly; their sins are lying like a heavy load upon them, and torturing them indescribably. They long to go through some form of prescribed penance. ${ }^{, 23}$ Cardinal Nicholas Wiseman, as early as 1848, pointedly contrasted English Catholic priests, who 'saw the poor in flocks round the confessional' with the Anglo-Catholic ministry, which remained 'powerless and flat among the masses. ${ }^{24}$ Anglo-Catholics, who evidently felt there was some truth in the jibe, experimented with auricular confession at their

21 'Of the Sacred Stigmata', The Life of St Francis of Assisi by St Bonaventure (from the 'Legenda sancti Francisci'), ed. Cardinal [H. E.] Manning, 9th edn. (London 1925 [1867]), 121-130.

22 Franciscan Tertiary Manual (Pantasaph, Holywell, 1904), 179.

23 As cited in John Kent, Holding the Fort: Studies in Victorian Revivalism (London: Epworth Press, 1978), 264-5.

24 N. Wiseman, Conversion: A Letter to Mr Alexander Chiriol and His Family on Their Happy Admission to the Communion of The Holy Catholic Church (London, 1848), 33 as 
twelve days' mission of 1869 and London mission of 1874, and soon began to adopt Franciscan devotions as well. Some Anglicans converted to Roman Catholicism precisely because their need for penance had not been satisfied in the Church of England. Lady Georgiana Fullerton, who became a Catholic in 1846 and quickly joined the Third Order of St Francis, became a devotee not only of confession, but also of the Franciscan 'way' or 'stations' of the cross. This quintessentially Franciscan devotion, which had been unfamiliar to most English Catholics before 1840, but had spread to all dioceses by the $1860 \mathrm{~s}^{25}$ soon became a normal feature of retreats and 'missions' held by Passionists, Redemptorists and Jesuits, as well as Franciscans.

The Franciscan devotions to the 'stations' or 'way' of the cross complemented Evangelical Victorians' own tendencies to focus on the crucifixion. At a time when the religious and moral consequences of industrial degradation and poverty were stirring the consciences of many middle-class Victorians, St Francis also came to be seen as a model of how genuinely Christian charity might be practised. Disagreements among Protestants about the validity of distinguishing between the 'deserving' and 'undeserving' poor were reflected in Victorian lives of St Francis, which agreed that the saint's devotion to Lady Poverty had been truly Christian, but hotly debated whether or not he could be understood as having endorsed begging. The medieval ideal of caritas, in which people had 'made themselves familiar with wretchedness, and by personal sympathy, no less than pecuniary aid, strove to mitigate the sufferings under which the afflicted were bowed down' presented a contrasting model to the poor laws, whose iniquities had so scandalised the Quaker Frederick Lucas that he converted to Catholicism in $1839 .{ }^{26}$ The idea that the givers and receivers of charity were equally holy, which Robert Donovan and Sheridan Gilley have identified as the distinguishing mark of the nineteenth-century Catholic charitable effort, ${ }^{27}$ was most closely associated with the Society of St Vincent de Paul (which Lucas brought to England in 1844) and with the Third Order of St Francis, which spread throughout the English Catholic community from the 1840s, reaching all dioceses by 1860 . It was because Franciscan

cited in Sheridan Gilley, 'Heretic London, Holy Poverty, and the Irish Poor, 1830-1870', Downside Review 89 (1971): 80.

${ }^{25}$ For the relevant devotional statistics for the Catholic churches of England and Wales from 1850 to 1914, see Mary Heimann, Catholic Devotion in Victorian England (Oxford: Clarendon Press, 1995), 174-190.

26 Robert K. Donovan, 'The Denominational Character of English Catholic Charitable Effort, 1800-1865', Catholic Historical Review, 62 (1976): 206. (Hereinafter cited as Donovan, 'The Denominational Character').

${ }_{27}$ See Donovan, 'The Denominational Character', 200-223; Gilley, 'Heretic London', 64-89; Sheridan Gilley, 'Papists, Protestants and the Irish in London, 1835-70', in G. J. Cuming and D. Baker, eds., Popular Belief and Practice, Studies in Church History 8 (1972), 259-66. 
tertiaries aimed to transform their attitudes to the poor-vowing, like Lady Georgiana Fullerton in 1857, to 'practise poverty in every way in my power' and to offer 'ardent prayers to St Francis to obtain for me the five virtues of humility, obedience, mortification, love of poverty, and patience' - that socially-minded Anglicans were drawn to the Franciscan way. ${ }^{28}$ John Ruskin, for example, was so impressed that he considered becoming a Catholic simply in order to be allowed to join the Third Order of St Francis. ${ }^{29}$

By the second half of the nineteenth century, a number of factors had combined to make St Francis seem far less alien to British sensibilities than would have been possible before. Evangelical earnestness and attention to the crucifixion and a widespread romantic yearning for an age of faith thought to have existed in the middle ages, combined with the attractive simplicity of the poverello's approaches to faith, charity and penance, made Protestant publishers willing to look to the previously neglected saint as a suitable model for a morally improving Christian life. The Sunday Library for Household Reading was the first Protestant series to commission a fresh life of the saint, and the task was undertaken by the Scottishborn Margaret Oliphant, herself introduced to the Acta Sanctorum by Carlyle in $1861 .^{30}$

Mrs Oliphant's Francis of Assisi, first published in 1868, offered a highly sympathetic portrait of one who 'cared for nothing save Christ and Him crucified - except indeed Christ's world, the universe redeemed, the souls to be saved, the poor to be comforted, the friends to be cherished, the singing bird and bubbling fountains, the fair earth and the sweet sky'. ${ }^{31}$ Mrs Oliphant's Francis was at once a romantic hero and a practical reformer; a chivalrous knight and a nature-poet whose love of the Umbrian countryside anticipated nineteenth-century aestheticism, yet whose 'wholly evangelical' spirit enabled him to transcend the narrow confines of thirteenth-century Catholic culture. ${ }^{32}$ Acutely conscious of her duty as an historian to empathise with the age in which her subject lived, and evidently charmed by the romance of the Fioretti, Oliphant was at pains to distinguish between those stories surrounding the saint which she judged to be 'simply legendary, produced by the gradually expanding superstition of the order, and its desire to raise its Founder to the highest fabulous rank of sainthood, or rather of semi-deity' and 'those which contained 'a hidden soul of meaning, such as the vulgar miss,

28 The Inner Life of Lady Georgiana Fullerton (London 1899), 43-4.

29 Seton, 'The Rediscovery', 251-2.

30 The Autobiography and Letters of Mrs M.O.W. Oliphant, ed. Mrs Harry Coghill (Edinburgh and London: Blackwood, 1899), 73.

31 Margaret Oliphant, Francis of Assisi (London, 1907 [1868]), 295. (Hereinafter cited as Oliphant, Francis of Assisi).

32 Oliphant, Francis of Assisi, xi. 
yet are strangely moved by, without knowing why. ${ }^{33}$ A truly Christian understanding of the saint's life, it seemed, fell somewhere between the twin extremes of a doctrinaire medieval Catholicism which 'shaped every detail of his life so as to place it in exact correspondence with that of our Lord', and an overly rationalistic brand of nineteenthcentury Protestantism which was tempted 'to explain everything wonderful' away through the reductionist science of textual criticism. ${ }^{34}$

The real St Francis, as Mrs Oliphant described him, was recognisably Evangelical in his moral earnestness, his emphasis on missionary work, and in his establishment of a lay society for those ordinary men and women who were asked to make "no sacrifice beyond that of the heart' and became the 'Puritans of that distant age, the Society of Methodists, the children of the new light'. ${ }^{35}$ But he was also a man about whom 'incidents full of poetic beauty' quite naturally gathered and whose reputation for miracles was not to be dismissed out of hand. ${ }^{36}$ Taking it as an axiom that 'every true revival of religion is unquestionably accompanied by signs which are not trickery, and cannot be entirely the creation of morbid fancy and enthusiasm', Mrs Oliphant was prepared to find rational grounds for belief in Francis's miraculous cures and legendary power over animals and was even willing to entertain the possibility of a supernatural explanation of the stigmata. ${ }^{37}$ Although she invariably concluded that there was not enough evidence, one way or the other, to pronounce on the authenticity of individual miracles, she implied that the fault might lie more with nineteenth-century scepticism than with thirteenth-century credulity. What made her portrayal distinct from those of earlier, more sceptical critics was her readiness to entertain the possibility of miracles, to insist that 'no popular return to the habits of piety has ever been made from the time of the Apostles, without the occurrence of certain spiritual phenomena which cannot be entirely explained away by any theory.38 ${ }^{38}$ It was this openness of approach which earned her praise from an English Catholic reviewer for having written of the saint 'with affection and even devotion', for using a method 'surprisingly pleasant for a Protestant', and for having 'said but little that a Catholic might not have said'. ${ }^{39}$

Mrs Oliphant's biography of St Francis was acceptable not only to English Catholics - though thought to be in need of slight doctrinal correction here and there-but also to Victorian sensibilities more generally. Ralph Townsend has argued that it would be hard to find

33 Oliphant, Francis of Assisi, xv, 117.

${ }^{34}$ Oliphant, Francis of Assisi, 165, 115.

${ }^{35}$ Oliphant, Francis of Assisi, 76, 206.

36 Oliphant, Francis of Assisi, 130.

37 Oliphant, Francis of Assisi, 23, 199; 239-40.

38 Oliphant, Francis of Assisi, 23.

39 'Mrs Oliphant's life of St Francis of Assisi', The Month 14 (1871), 544, 543. 
another religious life which more 'fairly represents the English spirit of saintly heroism of the nineteenth century'. 'Evangelical in tone, historical and judicious', it satisfied, as he has pointed out, 'most nineteenth-century heroic demands: Kingsley's requirement of a heroism in the nature of self-sacrifice, Carlyle's admiration of the vivid and radical medieval Church, Mozley's belief in the poetical hero, De Vere's notion of the saint as an heroic spectre of Christ' ${ }^{40}$

Since no contemporary discussion of St Francis could avoid touching, if only by implication, upon the deeper and more sensitive matter of how the life of Jesus, and consequently the meaning of Christianity, ought to be seen, Mrs Oliphant's Francis of Assisi also reaffirmed the certainties of traditional faith. In the face of doubts about gospel miracles that had been made particularly acute by the publication of Essays and reviews in 1860, she affirmed the enduring reality of the supernatural and chastised the Victorian public for its tendencies towards scepticism. In stressing Francis's likeness to Christ, and being prepared to recognise a common spirit in all 'genuine' Christianity, whether technically Evangelical, Methodist or Catholic, her portrait also offered what was in effect a bridge between traditional Christians of all denominational backgrounds.

Alongside numerous reprintings of Mrs Oliphant's biography, traditionally-minded Catholic presentations of the saint continued to be published throughout the 1870s and 1880s. These included works such as the Popular Franciscan Library's Flowers from the garden of St Francis for every day in the year (1879), Léopard de Chérance's Saint François d'Assise (first translated into English in 1880) and Léon de Monnier's devout Histoire de Saint François (1889). The battle between Catholic and Protestant, supernaturalist and rationalist, Biblical traditionalist and textual critic, took a long time to come but hit English readers, and hard, with the appearance, in 1894, of the Swiss Calvinist Paul Sabatier's Life of St Francis.

Paul Sabatier, who followed self-consciously in the footsteps of his teacher and mentor Ernest Renan, took it as his first premise that the task of distinguishing the 'legend' of St Francis from his true 'history' was the only honest and manly way of approaching the saint. ${ }^{41}$ Traditional Catholic hagiographies of St Francis, he claimed, had 'done him ill-service' by insisting on the incorporation of supernaturalism and a rigid conformity to the pattern of the saints. 'By such means the saints, perhaps, gain something in respect of the superstitious', he scoffed; but 'their lives lose something of virtue and

40 Ralph Townsend, 'Hagiography in England in the nineteenth century: a study in literary, historiographical and theological developments' (unpublished DPhil dissertation, Oxford, 1981), 182-4.

41 Paul Sabatier, Life of St Francis Assisi (London, 1901 [1894]), xxxiv. (Hereinafter cited as Sabatier, Life of St Francis). 
of communicable strength. Forgetting that they were men like ourselves, we no longer hear in our conscience the command "Go and do likewise". ${ }^{42}$

The Francis of Assisi that Sabatier claimed to have discovered was no meekly obedient son of the Church of Rome. Rather, he was a social revolutionary and proto-Protestant whose return to the unadorned Gospel message and insistence on the creation of a lay movement 'saved Christianity' from the corruptions of the medieval church so that, for a few years at least, Christendom could 'turn in amazement to Assisi as to a new Bethlehem. ${ }^{43}$ Such 'heights' of nobility as could be seen in the saint's life, which reached 'not to a sect, but to humanity', had been sadly travestied by an uncomprehending Catholic church, whose own presentation of St Francis as 'from the very cradle surrounded with aureole and nimbus' obscured the heroism of a man 'infinitely nobler than they have made him to be. ${ }^{, 44}$

Sabatier's portrait, which was translated into English within a year of publication and went into some forty-five editions and a score of languages, was not only more forcefully Protestant than anything which had previously appeared in English: it was also far more dismissive of explanations which could not be understood in purely human and natural terms. Claiming the authority of newly 'scientific' methods of textual criticism, Sabatier's work presented what seemed an authoritative challenge to the comfortable compromise- between legend and history, naturalism and supernaturalism, Protestantism and Catholicism - which had so warmed the hearts of Mrs Oliphant's readers. Where Mrs Oliphant had hesitated over the difficulties of historical sources, Sabatier was confident; where she saw merit in an age of Christianity portrayed as at once more infantile, but more devout, than her own, he detected institutional corruption and the speedy reversal of Francis's most cherished ideals; where she had left it to the reader to decide upon the sensitive question of the stigmata, he dismissed belief in miracles as 'immoral' and suggested that it was to the realm of 'mental pathology', not supernaturalism, that one should turn for a plausible explanation of what had happened at La Verna. ${ }^{45}$

Just as Renan's notorious Vie de Jésus of 1863, which it had sickened George Eliot to have to translate into English, had portrayed the preacher of Galilee as being nothing more than an example of moral excellence, so Sabatier's presentation of St Francis as a wholly admirable, but exclusively human, hero trampled on the delicate balance being struck by pious and morally earnest Englishwomen and Englishmen from every shade of religious - and, increasingly — irreligious

42 Sabatier, Life of St Francis, xxxiii, xxxiv.

43 Sabatier, Life of St Francis, 29, 52.

44 Sabatier, Life of St Francis, xxiii, xvi, xxxiii.

45 Sabatier, Life of St Francis, 433, 434. 
opinion-to claim St Francis as their own. Once the debate had been opened up, there was a positive scramble. From the 1890s scores of romanticised appreciations of Francis the troubadour, Francis the poet, and Francis as the subject of Giotto's paintings or Dante's verses began to flood the market. Dozens of socialist-minded or humanitarian biographies - books with amiable titles like Everybody's St Francis; Francis, the little poor man of Assisi; Francis, the apostle of humaneness and Saint Francis of Assisi, social reformer-soon followed. The Little flowers, first translated into English in 1864, was issued as a Temple Classic in 1896, re-released as an Everyman in 1906, and by 1925 had become a 'World Classic'. By 1891, the first Anglican third order of St Francis, which was granted formal recognition in 1898, had been set up; and in 1921 the first Anglican community of Franciscans, officially approved as a Franciscan congregation within the Church of England in 1931, established itself at Batcombe in Dorset. ${ }^{46}$ St Francis, it seemed, was no longer the exclusive property of Catholics, but had become the darling of high, broad and low-church Anglicans; Protestants; aesthetes; agnostics; socialists; and even atheists.

By the turn of the nineteenth century and the early decades of the twentieth, the change in popular attitudes to St Francis - in Britain as on the European continent - could hardly have been more complete. Francis of Assisi had come, not merely to be admired, but to be championed with a degree of warmth that can be compared in intensity only to the cult that had surrounded him in the thirteenth and fourteenth centuries. The most obvious change in atmosphere could be seen in the sheer number of hagiographies and biographies that were written and published in these years. Whereas English-language biographies of the saint had been appearing at about the rate of one or two per decade from the 1520 s to the 1860 s, between 1890 and 1939 more than 150 new or newly issued biographies, all of which found something to commend in the life and teaching of the holy man of Assisi, were published in England alone: and the number of selections from the saint's writings which was issued in the same period was comparably great. New lives, each of which drew Francis in the likeness of its own denominational image, became familiar Sunday reading for children and adults alike. In her Brother Francis: or less than the least of 1896, Staff-Captain Eileen Douglas of the Salvation Army stressed Francis's vital religion, soldierly bearing, missionary endeavours and, above all, his establishment of a lay society, the Third Order or 'brethren of the militia of Jesus Christ' as 'one of the most powerful religious, social and political influences the world has ever felt. ${ }^{, 47}$

46 See http://hilfieldfriary.org.uk/all-about-hilfield/.

47 Eileen Douglas, Brother Francis: or, Less Than The Least, $2^{\text {nd }}$ edn (London 1896), 106. (Hereinafter cited as Douglas, Brother Francis). 
Catholic corrections to what were perceived as Protestant errors rapidly followed: the Catholic Truth Society, for example, launched a series of magic-lantern lectures about St Francis to tour the British Isles. A selection of Catholic churches in London, Liverpool and Birmingham were granted an extension of the privileges of the Portincula indulgence. ${ }^{48}$ The Anglican third order of St Francis, equally determined to protect the supernatural elements of the holy saint's life, began at the turn of the century to campaign in earnest for formal recognition in Lay priesthood, or a plea for the constitution of the third order after the method of S. Francis d'Assisi [sic] and $S$. Francis of Assisi and the third order in the Anglo-Catholic church, both of which came out in 1898. The first popular edition of the Little flowers was brought out as a Temple Classic in the same year, 1898. Arnold Toynbee, an Anglican, later remembered how, all through his childhood, it lay on his parents' bedside table. ${ }^{49}$ Sabatier's presentation to the world of the Speculum Perfectionis, also in 1898, not only laid the foundations for modern Franciscan studies, but also revealed that there was a potentially huge market for popular editions of medieval texts such as the Little flowers, St Bonaventure's Life and that of the Three Companions; all of which were printed in successive cheap editions throughout the twentieth century.

In 1826, the six-hundredth anniversary of the death of St Francis of Assisi had passed completely unnoticed outside of Italy. By 1926, the saint was acknowledged everywhere as a figure of universal importance. His image was proudly displayed on commemorative stamps. The British Society of Franciscan Studies, which had been in existence since 1902, put together a special display at the British Museum. Two million people went on pilgrimage to Assisi. A papal encyclical described Francis as a 'second Christ (alter Christus)'. Benito Mussolini, ever alert to new ways to link Catholicism and Italian patriotism to his Fascist movement, paid loud tribute to 'il piú santo dei santi al Cristianesimo e all' umanità' in a rousing speech to the Italian nation. ${ }^{51}$

Confronted with a plethora of new lives, together with cheap popular editions of Franciscan sources, religious biographers became increasingly militant in putting forward distinctively Protestant or Catholic interpretations of the saint's significance. The Methodist

\footnotetext{
48 The Catholic Directory specified that the 'great indulgence of the Portiuncula' could, for example, be obtained at St Mary of the Angels, Bayswater and St John the Evangelist's in Islington. The Catholic Directory and Annual Register (London 1865), 23-4; 31; 47.

49 Arnold Toynbee to Columba Cary-Elwes (2 May 1967), as cited in Christian B. Peper, ed. An Historian's Conscience: The Correspondence of Arnold J. Toynbee and Columba CaryElwes, Monk of Ampleforth (Oxford: Oxford University Press, 1986), 478.

50 As cited in Jaroslav Pelikan, Jesus Through the Centuries (New York: Harper and Row, 1985), 133 .

51 As cited in Seton, 'The Rediscovery', 246.
} 
John Telford's Thoughts from St Francis of Assisi of 1924 went so far in emphasising Francis's conformity to an Evangelical pattern that, although he found room to discuss the saint's 'conversion', 'call to preach' and 'missionary endeavours', he omitted even to mention the stigmata, let alone the wolf of Gubbio. Increasingly, when miracles were discussed at all, they tended to be explained away. The old theories that the "wolf' of Gubbio had really been a brigand named Lupo, or that the story of the stigmata had been invented by Brother Elias, were revived and widely circulated. To the legend that, when Francis and his companions first set sail for Spain, their supplies were miraculously made to last the journey, Staff-Captain Douglas of the Salvation Army offered an alternative explanation. 'The real fact', she ventured, 'was probably that the basket contained large supplies of beans, and lentils, and macaroni, and such Italian foods that swell in the cooking, and go a long way., ${ }^{52}$

As Protestant biographers grew increasingly reductionist in their readings of the supernatural elements of St Francis's life, Catholic authors became more insistent that Francis's spirituality was inextricably linked to the teaching of the Catholic Church, whose eternal truths were claimed to be more faithfully preserved in medieval legends than in contemporary Protestant lives. Works like F. E. Kenner's Portiuncula; or the celebrated indulgence granted by our lord Jesus Christ at the request of the seraphic father St Francis of Assisi (1914) or Father Augustine's St Francis and the blessed eucharist (1932), with its chapters on Francis's 'Reverence for priests', 'Love for the abiding presence' and 'Love for the mass' made clear how devotion to the saint ought to be expressed by good Catholics.

To conflicting Protestant and Catholic interpretations were increasingly added agnostic, and even atheist, portrayals. Socialist lives tended to be broadly Protestant in their acceptance of the notion, strongly urged by Sabatier and others, that St Francis represented a sort of morning star of the Reformation, and followed their lead in finding rational explanations for purported miracles. They also took from Protestant biographies the notion that the early Franciscans had launched a social revolution in medieval society, but went further in stressing its political implications. Seeing in the life of St Francis a bold restatement of gospel injunctions to create a just society, or kingdom of heaven, on earth, Francis was presented as a protosocialist revolutionary whose aim was to overthrow the practices of a corrupt theocracy and whose Third Order aimed to establish a classless society. This made him heroic, and relevant, even to Fabians, Socialists and Communists.

52 Douglas, Brother Francis, 89. 
Although men and women in the nineteenth and twentieth centuries increasingly held St Francis dear, they were divided over how the object of their admiration should be seen. At the heart of their differences lay the question of whether the originally medieval Catholic features of the saint's life should be seen as historical accidents, deliberate distortions on the part of Catholic biographers, or essential to grasping his spirituality and religious message. While all could agree in praising Francis's likeness to Christ, attitudes to poverty and simplicity of heart, biographers differed as to what these concepts meant. To some, poverty was a holy state to be emulated, while to others it was a social problem to be solved or simply the proper object of charitable benevolence. Some understood simplicity to mean a childlike trust in the supernatural; others an unquestioning obedience to the Church; still others as the rejection of all institutional religion. Since the question of whether medieval legends should be taken as literally or allegorically true was thought to have a direct bearing on the reality of the supernatural and the credibility of gospel narratives, debates about St Francis revealed not only sharpening denominational divisions, but also changing attitudes towards the plausibility of Christianity itself.

The late nineteenth-century and early twentieth-century explosion of interest in St Francis of Assisi came about as the result of the attempt individual authors, each representing a distinctive shade of theological or moral opinion, to claim the saint as his or her own and so to promote correct religious teachings or ethical understandings of the world. But the existence of so many conflicting accounts and interpretations enabled the seeker after religious or moral truth to claim the saint's endorsement for almost any mix of religious, or quasireligious, sentiments. The Franciscan scholar F. C. Burkitt recalled with horror in 1931 how:

A very intelligent lady of my acquaintance professed to me a great interest in St Francis, but a chance remark brought out the fact that she had never read any of the Speculum Perfectionis. I don't mean that she preferred Lemmens's text to Sabatier's; she did not know any form of that great collection of anecdotes. So I lent her Mr Steele's translation, the well-known little book in the Temple Classics. But what was the result? She told me, 'I read it with much interest, but I am afraid that I like the Francis of the Little Plays better than this one! And,' she added. 'I know this is the real one. ${ }^{53}$

'Sanctity', considered the president of Magdalen College, Oxford in 1936, 'is a perplexing subject because it passes our common understanding, and the cult of the saints has had curious practices... but the Christian thought of the world has found in [Francis of Assisi]

53 F. C. Burkitt, 'St Francis of Assisi and Some of His Biographers', in F. C. Burkitt, H. E. Goad and A. G. Little, eds., Franciscan Essays, 2 vols (Manchester: Manchester University Press 1932), 2: 20. 
a most especial holiness. ${ }^{54}$ Through selective readings of the saint's life - or by concentrating only on the most palatable aspects of his piety, such as his attitudes to poverty, to nature or to the infant Jesus - it was quite possible to feel devotion to Francis in scarcely Christian, let alone rigorously Catholic, terms. As Pius XI felt obliged to remind the world in 1926, in the face of increasingly sentimental appropriations of the saint, 'the herald of the great king did not come to make men doting lovers of flowers, birds, lambs, fishes or hares; he came to fashion them after the Gospel pattern, and to make them lovers of the cross. ${ }^{55}$ The writer G. K. Chesterton, himself a convert to Catholicism, tried a gentler approach: rather than asking his readers to abandon the purely secular elements of their admiration for the saint, he invited them instead to believe that there was a higher understanding of sanctity to be found in the Catholic tradition. 'I too have lived in Arcady', he wrote; 'but even in Arcady I met one walking in a brown habit who loved the woods better than Pan. ${ }^{56}$ Even so, at a convention of ecologists taking place in Florence in 1931 it was decided to make on 4 October, St Francis of Assisi's feast day, 'World Animal Day'. ${ }^{57}$

By the second half of the twentieth century, St Francis's popularity was as strong as ever, but his message had become so diluted and transformed by the existence of hundreds of alternative - often mutually contradictory - biographies that he could no longer be said to be generally understood as a specifically Catholic saint. Francis's relations with animals, once interpreted as indicating a reversal of the enmity created between man and the animals after the Fall, had come to symbolise an almost pantheistic union with nature, an interpretation which was only reinforced by popular ecological and, later, New Age, sentiment. Just as Francis's preaching to the birds and kindly dealings with animals had come to be sentimentalised in ways that would have been foreign to thirteenth-century and fourteenthcentury chroniclers, so those aspects of his life that seemed most uncompromisingly Catholic began to be quietly omitted from all but explicitly Catholic histories. The stigmata, first called into question by Protestant biographers as a fraud, a symptom of psychopathology or, at best, a natural response to an extraordinary degree of empathetic meditation on the Passion, were increasingly left out of popular biographies. Francis's devotion to the virgin Mary and to the blessed sacrament, like his association with the crusades and determination to convert infidels to the 'true faith', were not only forgotten, but would have seemed out of place with most people's conception of the saint.

54 T. S. R. Boase, St Francis of Assisi (London: Thames and Hudson, 1968 [1936]), 113.

55 As cited in Seton, 'The Rediscovery', 258.

56 G. K. Chesterton, St Francis of Assisi (London: Hodder and Stoughton, 1944), 16.

57 http://www.worldanimalday.org.uk/. 
During the First World War, in the place of Francis's actual writings - some of which were disturbingly mystical and all of which were doctrinally Catholic - the so-called 'Peace prayer' or 'Prayer of St Francis', a prayer incorrectly attributed to St Francis of Assisi, spread widely. By the late 1960s, the 'Prayer of St Francis' had become a familiar sight on countless tea-towels, post-cards, and posters of sunsets and beaches:

Lord, make me an instrument of your peace.

Where there is hatred, let me sow love.

Where there is injury, pardon.

Where there is doubt, faith.

Where there is despair, hope.

Where there is darkness, light.

And where there is sadness, joy.

It was this unobjectionably nondenominational text (albeit slightly altered, the secular words 'truth' and 'error' having been made to replace the explicitly religious terms 'faith' and 'doubt') that Margaret Thatcher invoked on the steps of 10 Downing Street after her election victory in 1979. In the same year, Pope John Paul II proclaimed St Francis to be the 'patron saint of ecologists'. The 'Prayer of St Francis', with its references to 'faith' and 'doubt' restored, was sung at the funeral of Diana, Princess of Wales in 1997, when it was heard by an estimated 2.5 billion people around the world. ${ }^{58}$

An animated cartoon, 'A day in the life of St Francis', evidently aimed at Catholic pre-schoolers, can be watched on YouTube (2017). In the animation, St Francis - presented as a tonsured, habited Franciscan friar-sets off to town one day to preach a sermon. Along the way he is distracted by the need to rescue a kitten, help a farmer, cheer up a blind man, and join a group of children in a game of football. All these little diversions take up so much of his day that, by the time night falls, St Francis has yet to have reached town or delivered his sermon. The punch line, or rather the moral, of the story is that he had in fact been 'preaching' the gospel all day long: through his acts of kindness. ${ }^{59}$

The rise in devotion to St Francis that became such a marked feature of English spirituality in the late nineteenth and early twentieth centuries seems to have come about for a number of reasons. A saint who boldly preached and lived the gospel, Francis appeared to earnest Victorians to offer a timely rebuke to those tendencies of which they were the most ashamed: materialism, the loss of 'simple faith' and

\footnotetext{
58 http://news.bbc.co.uk/onthisday/hi/dates/stories/september/6/newsid_2502000/2502307.stm.

59 'A day in the life of St Francis' as published by www.theamazingcat.com. The short cartoon can be viewed at: https://www.youtube.com/watch?v=JtSvwOOOTBI, accessed 18 April 2016 and 11 January 2017.
} 
uneasy doubts about the reality of the supernatural dimension of life. Although they saw him very differently in doctrinal and theological terms, Victorian Evangelicals, Anglicans and Catholics could all agree that St Francis had been animated by a truly Christian spirit of charity and penitence. Ernest Renan was surely not the only liberal sceptic to find consolation in the thought, expressed by a Capuchin friar, that although he had spoken improperly of Christ, he had spoken with such warmth of the 'one perfect Christian' after Jesus that St Francis would surely save him. ${ }^{60}$

Francis of Assisi was for centuries perceived, and with good reason, as one of the most uncompromisingly Roman Catholic of saints. All the evidence left to the Victorians suggested that he was hard-edged in doctrine, distinctive in devotion, unapologetically supernaturalist, literal in his interpretation of scripture and wholeheartedly obedient to papal directives. Nevertheless, from the turn of the nineteenth and twentieth centuries, St Francis of Assisi became increasingly popular as he simultaneously became increasingly malleable, inclusive and denominationally indistinct. No longer seen as a controversial reformer, or a troubling mystic, in our own day St Francis of Assisi has come to be understood as a saint for all seasons. This makes him an especially apt and inclusive symbol of current Christian endeavour to remain relevant, accessible and catholic in a secularised, but not necessarily indifferent, world.

60 See Ernest Renan, 'François d'Assise', Nouvelles études d'histoire religieuse (Paris 1884) and Seton, 'The Rediscovery', 249-50. 